DOI: $10.19195 / 0524-4544.328 .13$

\title{
LUCYNA BUDKIEWICZ-SZCZUPAK
}

ORCID: 0000-0002-3039-0092

Uniwersytet Mikołaja Kopernika w Toruniu

1.budkiewicz@wp.pl

\section{Program nauczania prawa na Wydziale Prawa Uniwersytetu Mikołaja Kopernika w Toruniu w latach 1945-1962}

Celem niniejszego artykułu jest ukazanie, na przykładzie programu nauczania prawa na Wydziale Prawa Uniwersytetu Mikołaja Kopernika w Toruniu w początkowych latach jego istnienia, problemów odnoszących się do kształcenia prawników. Są one ciągle aktualne mimo podpisania przez Polskę deklaracji bolońskiej, która miała przyczynić się do stworzenia do 2010 roku europejskiego obszaru szkolnictwa wyższego. Służyć temu miało przyjęcie porównywalnych tytułów zawodowych, suplementu do dyplomu, systemu opartego na dwóch głównych cyklach kształcenia - studiach pierwszego i drugiego stopnia, ustanowieniu punktów zaliczeniowych, promowanie mobilności likwidowaniem przeszkód utrudniających swobodę przemieszczania się studentów i naukowców, promowanie współpracy europejskiej w zakresie zapewniania jakości służącej opracowaniu porównywalnych kryteriów i metodologii, a także niezbędnego wymiaru europejskiego w szkolnictwie wyższym, zwłaszcza w pracach nad tworzeniem programów nauczania, współpracy międzyuczelnianej.

Nauczanie prawa na Uniwersytecie Mikołaja Kopernika w Toruniu rozpoczęło się w roku akademickim 1945/1946, jednakże w latach 1954-1957 pracę Wydziału Prawa zawieszono i działalność naukowo-dydaktyczna nie była prowadzona. W niniejszym opracowaniu przedstawiono program nauczania prawa do roku 1962, zatem pierwsze programy nauczania po powstaniu Wydziału Prawa na Uniwersytecie Mikołaja Kopernika w Toruniu oraz po reaktywacji Wydziału Prawa w roku 1958/1959. 
W początkowych latach działalności Wydziału korzystano z przedwojennego programu Uniwersytetu Poznańskiego z roku akademickiego 1935/1936 ${ }^{1}$. Charakterystyczną cechą ówczesnego kształcenia był podział roku na trymestry, trwające po dziesięć tygodni. Studia na wydziałach prawniczych kończyły się rocznymi egzaminami składanymi przed komisją wydziałową ${ }^{2}$. Komisja oddzielnie oceniała każdy przedmiot, a w wypadku uzyskania oceny niedostatecznej z jednego przedmiotu studentowi należało umożliwić zdawanie egzaminu poprawkowego po wakacjach. Student, który otrzymał ocenę niedostateczną z dwóch lub więcej przedmiotów, zobowiązany był powtórzyć rok. Zgodnie z rozporządzeniem Ministra Wyznań Religijnych i Oświecenia Publicznego z dnia 16 października 1920 roku w sprawie organizacji studiów prawnych na uniwersytetach państwowych nauka trwała dwanaście trymestrów, czyli cztery lata, a program był jednolity na wszystkich wydziałach prawa w Polsce ${ }^{3}$.

Program minimalny, który mógł zostać zwiększony przez Radę Wydziału, zakładał nauczanie na pierwszym roku przedmiotów: prawo rzymskie (sto sześćdziesiąt godzin), teoria prawa (czterdzieści godzin), historia prawa polskiego - ustroju oraz prawa sądowego (sto osiemdziesiąt godzin), historia prawa na zachodzie Europy (sto dwadzieścia godzin), na drugim roku: prawo kościelne (dziewięćdziesiąt godzin), ekonomia polityczna, obejmująca teorię, historię doktryn oraz politykę ekonomiczną (sto osiemdziesiąt godzin), prawo polityczne wraz z nauką o państwie (sto godzin), prawo narodów (sześćdziesiąt godzin), na trzecim roku: skarbowość i prawo skarbowe (dziewięćdziesiąt godzin), nauka administracji i prawo administracyjne (sto osiemdziesiąt godzin), statystyka (sześćdziesiąt godzin), prawo karne i postępowanie karne (sto dwadzieścia godzin), filozofia prawa (czterdzieści godzin), na czwartym roku — prawo cywilne (dwieście dziesięć godzin), postępowanie cywilne sądowe (sto pięćdziesiąt godzin), prawo handlowe i wekslowe (dziewięćdziesiąt godzin), prawo międzynarodowe prywatne (trzydzieści godzin). O rozkładzie zajęć w czasie roku decydowały rady wydziałów, pamiętając, że w trzecim trymestrze zajęć ma być mniej, aby umożliwić studentom przygotowanie się do egzaminów rocznych ( 33 rozporządzenia). Radom wydziałów pozostawiono oznaczenie liczby godzin seminariów, które powinny być prowadzone z wszystkich przedmiotów obowiązkowych, natomiast

1 E. Gajda, Krótki rys historii Wydziału Prawa i Administracji UMK w Toruniu, [w:] Ze Złotej Księi Wydziału Prawa i Administracji Uniwersytetu Mikołaja Kopernika, red. S. Salmonowicz, M. Sobczyk, Toruń 2015, s. 16.

2 W skład komisji wchodzili profesorowie zwyczajni i nadzwyczajni wykładający przedmioty egzaminacyjne oraz inni członkowie komisji mianowani przez Ministra Wyznań Religijnych i Oświecenie Publicznego na wniosek Rady Wydziału.

3 Rozporządzenie Ministra Wyznań Religijnych i Oświecenia Publicznego z dnia 16 października 1920 roku w sprawie organizacji studiów prawnych na uniwersytetach państwowych, Dz. Urz. Ministerstwa Wyznań Religijnych i Oświecenia Publicznego 1920 nr 22, poz. 140, http://mbc.cyfrowemazowsze.pl/dlibra/docmetadata $\mathrm{id}=15774 \&$ from $=\&$ dirids $=1 \&$ ver_id $=\& 1 \mathrm{p}=107 \& \mathrm{QI}=9 \mathrm{CB}-$ D2EEBCBEEDA1C46EC0149C0167123-116 (dostęp: 15 października 2017). 
z przedmiotów nieobowiązkowych wydziały powinny zapewniać ich wykłady studentom i udostępnić je odpowiednim rozkładem godzin ${ }^{4}$.

Program ten nieznacznie zmodyfikowano rozporządzeniem Ministra Wyznań Religijnych i Oświecenia Publicznego z dnia 12 sierpnia 1939 roku w sprawie organizacji studiów prawnych w szkołach akademickich, które jednak zostało ogłoszone dopiero po wojnie ${ }^{5}$. Na pierwszym roku studiów prawniczych przedmiot teoria prawa zastąpiono wstępem do nauk prawnych - w wymiarze czterdziestu godzin, zmniejszono wymiar godzin prawa rzymskiego do stu pięćdziesięciu godzin, historii prawa polskiego do stu dwudziestu godzin, historii prawa na zachodzie Europy do dziewięćdziesięciu godzin. Naukę ekonomii politycznej podzielono na dwa lata - na pierwszym roku w wymiarze sześćdziesięciu godzin, a na drugim roku w wymiarze stu dwudziestu godzin. Na drugim roku studiów wprowadzono prawo cywilne, które również zostało podzielone na dwa lata, na drugim i trzecim roku — po sto dwadzieścia godzin. Zrezygnowano z przedmiotu prawo polityczne. Na trzecim roku zwiększono wymiar godzin przedmiotu prawo i postępowanie karne. Naukę administracji i prawa administracyjnego podzielono na dwa lata, po dziewięćdziesiąt godzin na trzecim i czwartym roku. Na czwartym roku zwiększono wymiar prawa handlowego i wekslowego do stu dwudziestu godzin, zmniejszono wymiar postępowania cywilnego do stu dwudziestu godzin oraz wprowadzono nowy przedmiot - filozofię w wymiarze czterdziestu godzin. Na każdym roku prowadzono ćwiczenia w wymiarze stu dwudziestu godzin. Zgodnie z rozporządzeniem każdy student przez cały tok studiów musiał uczestniczyć w ćwiczeniach $\mathrm{z}$ dwóch przedmiotów po dwie godziny tygodniowo, przy czym w co najmniej jednych ćwiczeniach z bloku przedmiotów historycznych, z grupy nauk ekonomiczno-prawnych, z nauk cywilistycznych oraz prawnopublicznych. Jednak ćwiczenia miały być wprowadzane w miarę możliwości budżetowych i personalnych szkoły, przy czym prymarne było wprowadzenie jednego ćwiczenia obowiązkowego dla każdego roku studiów, a następnie dopiero drugie. W okresie przejściowym, do czasu pełnej realizacji programu, rady wydziałów zobowiązane były przedkładać odpowiednie sprawozdania Ministerstwu ( $§ 12$ rozporządzenia z dnia 12 sierpnia 1939 roku).

Kwestia nauczania prawa była tematem dyskusji w środowisku prawniczym już od momentu odzyskania przez Polskę niepodległości. Po pierwszej wojnie światowej stanowiska praktyków ścierały się ze stanowiskami teoretyków. Praktycy uważali bowiem, że kształcenie prawników powinno przebiegać tak, aby po

4 Przedmiotami nieobowiązkowymi, lecz zalecanymi, zgodnie z rozporządzeniem z dnia 16 października 1920 roku były: socjologia, logika, psychologia, etyka, historia filozofii, medycyna sądowa, oraz przedmioty specjalistyczne, na przykład prawo górnicze, agrarne, polityka kryminalna i inne.

5 Rozporządzenie Ministra Wyznań Religijnych i Oświecenia Publicznego z dnia 12 sierpnia 1939 roku w sprawie organizacji studiów prawnych, Dz. Urz. Ministerstwa Oświaty 1945, nr 8 poz. 333; http://mbc.cyfrowemazowsze.pl/dlibra/plain-content?id=19364 (dostęp: 15 października 2017). 
zakończeniu studiów młodzi adepci prawa byli przygotowani do pracy w organach wymiaru sprawiedliwości, natomiast teoretycy sądzili, że absolwenci studiów prawniczych powinni mieć w pełni naukowe wykształcenie. Najbardziej znany spór dotyczący tej kwestii toczył się między profesorami Oswaldem Balzerem i Juliuszem Makarewiczem na łamach „Przeglądu Prawa i Administracji” w latach 1919$1921^{6}$. Kwestia modelu nauczania prawa jest żywo dyskutowana także dzisiaj.

W czasie gdy Wydział Prawa Uniwersytetu Mikołaja Kopernika w Toruniu dopiero się tworzył, na innych uniwersytetach toczyła się ożywiona dyskusja nad kształtem programu nauczania. Zauważmy, że środowisko prawnicze było bardzo osłabione po wojnie. Ubytki kadrowe spowodowane były śmiercią, emigracją, wywiezieniem do ZSRR. Jak zauważa Piotr Kładoczny, z liczby 3,5 tys. sędziów i prokuratorów przedwojennych po wojnie zostało zatrudnionych niespełna 1,3 tys. osób ${ }^{7}$.

W roku 1946 rozpoczęto przygotowanie reformy studiów prawniczych, która miała wydziałom prawa przywrócić dawną powagę. Zakładano, że umożliwi ona wykształcenie nowej kadry wymiarowi sprawiedliwości, świadomej społecznie i politycznie, przygotowanej do wykonywania zawodów prawniczych. Początkowo liczono, że uda się nawiązać współpracę z pracownikami akademickimi przedwojennych uniwersytetów, jednak ze względu na duży opór oraz znaczne braki wśród starszych pracowników władze Polski Ludowej nie znalazły większego poparcia ze strony dawnej kadry. Natomiast młodzi pracownicy nauki często godzili się na współpracę z władzą komunistyczną, mieli bowiem nadzieję, że działania zgodne z wytycznymi władz pomogą w rozwoju ich kariery naukowej ${ }^{8}$.

Poprzedniemu kształceniu prawników zarzucano, że zbyt dużą wagę przykładano do przedmiotów dogmatycznych, czego konsekwencją jest, że wydziały prawa wypuszczają na rynek pracy absolwentów niewystarczająco do pracy przygotowanych. Liczono bowiem, że dzięki reformie studenci zaraz po studiach nie będą wymagali dalszego przygotowania i mogli od razu podjąć pracę. Dlatego zamierzono zmniejszyć nacisk na naukę przedmiotów historycznoprawnych, szczególnie prawa rzymskiego, na rzecz przedmiotów bardziej specjalistycznych ${ }^{9}$.

Na podstawie delegacji z art. 75 ust. 1 dekretu z dnia 28 października 1947 roku o organizacji nauki i szkolnictwa wyższego ${ }^{10}$ wydano rozporządzenie Ministra Oświaty z dnia 23 grudnia 1949 roku w sprawie organizacji i planu studiów na

6 M. Marszał, Spór o model prawnika w Drugiej Rzeczypospolitej, „Krakowskie Studia z Historii Państwa i Prawa, Kraków” 8, 2015, z. 2, s. 174.

7 P. Kładoczny, Kształcenie prawników w Polsce w latach 1944-1989, „Studia Iuridica” 35, 1998, s. 90.

8 A. Watoła, Reforma studiów prawnych w latach 1949-1950, „Miscellanea Historico-Iuridica” 14, 2015, z. 2, s. 340-341, https://doi.org/10.15290/mhi.2015.14.02.21.

9 P. Kładoczny, op. cit., s. 90.

10 Dekret z dnia 28 października 1947 roku o organizacji nauki i szkolnictwa wyższego Dz.U. $1947 \mathrm{Nr} 66$, poz. 415. 
wydziałach prawa w państwowych szkołach akademickich ${ }^{11}$. Rozporządzenie zostało wydane za zgodą Rady Głównej do spraw Nauki i Szkolnictwa Wyższego, po wysłuchaniu opinii organów właściwych szkół, i ustalono szczegółowe przepisy normujące program oraz porządek studiów i egzaminów w szkołach wyższych ${ }^{12}$. W tym samym trybie określono organizację studiów specjalnych w szkołach wyższych. Na podstawie delegacji ustawowej Minister Oświaty określił ogólny plan wykładów i ćwiczeń prawniczych studiów pierwszego stopnia.

Rozporządzenie zmieniło znacząco organizację studiów. Studia prawnicze pierwszego stopnia stały się trzyletnimi studiami zawodowymi. Istniała również możliwość ukończenia studiów drugiego stopnia, które trwały rok. Ukończenie studiów pierwszego stopnia uprawniało do wykonywania zawodów prawniczych, natomiast stopień naukowy można było uzyskać jedynie po ukończeniu studiów drugiego stopnia. Podział roku akademickiego też zmienił się — były dwa semestry, przy czym każdy semestr nie mógł trwać krócej niż piętnaście tygodni.

W nowym programie studiów wskazano kolejność przeprowadzania kursów z każdego z przedmiotów i nawet liczbę godzin danego przedmiotu tygodniowo. Do nowego programu wprowadzono też nowe przedmioty. Na pierwszym roku: materializm dialektyczny i historyczny (dziewięćdziesiąt godzin rocznie, dwa semestry po trzy godziny tygodniowo), historię gospodarczą (sześćdziesiąt godzin rocznie, w pierwszym semestrze, cztery godziny tygodniowo), zagadnienia Polski współczesnej (sześćdziesiąt godzin rocznie, dwa semestry po dwie godziny tygodniowo). Na drugim roku wprowadzono nowy przedmiot - ustrój sądów, w wymiarze jednej godziny tygodniowo w trzecim semestrze, przy czym z tego przedmiotu ćwiczenia nie były obowiązkowe. Na trzecim roku wprowadzono przedmioty: prawna organizacja przedsiębiorstw (sześćdziesiąt godzin rocznie po cztery godziny tygodniowo, jedynie w piątym semestrze), prawo rzymskie prywatne (sto pięćdziesiąt godzin rocznie, przy czym dwie godziny tygodniowo w piątym semestrze i trzy godziny tygodniowo w szóstym semestrze) oraz prawo międzynarodowe publiczne (sto osiemdziesiąt godzin rocznie, przy czym trzy godziny tygodniowo w piątym semestrze i dwie godziny w szóstym semestrze). Ćwiczenia obejmowały wszystkie przedmioty. Każdy student zobowiązany był

11 Rozporządzenie Ministra Oświaty z dnia 23 grudnia 1949 roku w sprawie organizacji i planu studiów na wydziałach prawa w państwowych szkołach akademickich, Dz.U. z 1950 r. Nr 6, poz. 58.

12 Rada Główna, zgodnie z dekretem z dnia 28 października 1947 roku o organizacji nauki i szkolnictwa wyższego, była organem kolegialnym, w której skład wchodził przewodniczący — $\mathrm{z}$ urzędu był to minister oświaty lub reprezentujący go podsekretarz stanu oraz piętnastu członków powoływanych na trzy lata spośród z czynnych pracowników naukowych (art. 10 dekretu). Do głównych zadań Rady Głównej należało prowadzenie badań w zakresie spraw nauki i szkolnictwa wyższego, współdziałanie w sprawach nauki i szkolnictwa wyższego przy układaniu i wykonywaniu planów państwowych, inicjowanie projektów, dotyczących finansowania potrzeb nauki i szkół wyższych, a także projektowanie zasad specjalnego kształcenia kandydatów na pracowników naukowych i udzielanie stypendiów naukowych (art. 13 dekretu).

Prawo 328, 2019

(C) for this edition by CNS 
do odbycia dwóch ćwiczeń w ciągu roku w wymiarze stu dwudziestu godzin rocznie. Zaliczenie ich następowało zależnie od uznania kierownika ćwiczeń na podstawie wykonanych przez studenta prac lub kolokwium.

Zmieniono rozkład zajęć. Już na pierwszym i drugim roku nauczano prawa cywilnego, prawo administracyjne przeniesiono na drugi i trzeci rok, ekonomia była tylko na drugim roku. Zupełnie natomiast zrezygnowano z prawa rzymskiego, Ministerstwo Sprawiedliwości uważało bowiem ten przedmiot za wielce szkodliwy ${ }^{13}$.

Nowy program, obowiązujący od roku akademickiego 1946/1947, z możliwością odroczenia jego wprowadzenia o jeden rok, nie obejmował również wykładów z prawa narodów, prawa handlowego i teorii prawa. Dawny przedmiot historia ustroju i prawa polskiego zawężono jedynie do nauczania ustroju Polski, wstęp do nauk prawnych zamieniono na wstęp do nauki o państwie i prawie. Zamiast dwóch przedmiotów do wyboru - ustrój i prawo ZSRR lub ustrój i prawo anglosaskie - pojawił się jeden przedmiot obligatoryjny ustrój ZSRR. Prawo pracy zamieniono na prawo pracy i ubezpieczeń społecznych, nauka administracji i prawa administracyjnego ustąpiła miejsca prawu administracyjnemu.

W związku ze skróceniem podstawowego trybu studiów z czteroletniego na trzyletni konieczna okazała się zmiana rozkładu zajęć. Prawo cywilne przeniesiono na pierwszy i drugi rok studiów, prawo administracyjne na drugi i trzeci rok, ekonomię wykładano jedynie na drugim roku.

Każdy student był zobowiązany do uczestnictwa w ćwiczeniach. Odstąpiono od obowiązku ich odbywania jedynie z przedmiotów: wstęp do nauki o państwie i prawie, materializm dialektyczny i historyczny, zagadnienia Polski współczesnej, logika oraz ustrój sądów. Każdy student musiał odbyć praktyki zawodowe. Absolwenci trzeciego roku studiów prawniczych mieli możliwość podjęcia zatrudnienia w organach wymiaru sprawiedliwości. Mogli też ubiegać się o przyjęcie na czwarty rok studiów, po którego ukończeniu uzyskiwali tytuł magistra. Nie wszystkie jednak uniwersytety prowadziły drugi stopień studiów prawniczych. Zgodnie z § 1 uchwały nr 758 Prezydium Rządu z dnia 10 września 1952 roku w sprawie wykazu szkół wyższych uprawnionych do nadawania dyplomów o ukończeniu studiów drugiego stopnia lub równorzędnych oraz warunków i trybu ich nadawania w szkołach wyższych uprawnione do nadawania tytułu magistra były uniwersytety: Jagielloński, Warszawski, Wrocławski im. Bolesława Bieruta, Poznański, Łódzki, Mikołaja Kopernika w Toruniu, Marii Curie-Skłodowskiej w Lublinie ${ }^{14}$. Nie oznaczało to jednak, że wszystkie wydziały prawa prowadziły

13 P. Kładoczny, op. cit., s. 91; W. Wołodkiewicz w artykule Czy prawo rzymskie przestało istnieć? wskazuje, że częstym argumentem przeciwko prawu rzymskiemu, było to, iż przedmiot ten jest „wysoce szkodliwy, bowiem zaraża on psychikę młodego prawnika formułami myślenia magicznego z równoczesnym zatraceniem rozumienia prawa jako jednej z nauk społecznych”, „Palestra” 1997, nr 11-12, s. 72.

14 Uchwała nr 758 Prezydium Rządu dnia 10 września 1952 roku w sprawie wykazu szkół wyższych uprawnionych do nadawania dyplomów o ukończeniu studiów drugiego stopnia lub rów- 
studia drugiego stopnia. Możliwe to było początkowo jedynie na Uniwersytecie Jagiellońskim oraz Uniwersytecie Warszawskim, a następnie na uniwersytetach Poznańskim oraz Wrocławskim.

Studia drugiego stopnia miały być specjalistyczne. Na czwartym roku studiów prowadzono jedynie wykłady z materializmu dialektycznego, teorii państwa oraz ekonomii politycznej oraz wykłady specjalistyczne, które zależały od tego, jaką kadrą dysponował wydział mający uprawnienia do prowadzenia kursu drugiego stopnia. Na ostatnim roku studiów studenci musieli uczyć się języka rosyjskiego oraz innego nowożytnego języka obcego.

Podział studiów prawniczych na studia dwustopniowe nie miał żadnego racjonalnego uzasadnienia. Albowiem skoro absolwenci studiów trzyletnich i czteroletnich mieli takie same uprawnienia do wykonywania zawodów prawniczych, a w zasadzie cały program studiów, wcześniej obejmujący studia czteroletnie, skumulowany został w trzech latach, to podział na studia pierwszego i drugiego stopnia nie był logiczny. Wskazać przy tym należy, że istniała jeszcze jedna droga do wykonywania zawodów prawniczych, która nie wymagała ukończenia studiów wyższych, a mianowicie ukończenie średniej szkoły prawniczej przy Ministerstwie Sprawiedliwości. Marcin Zaborski podaje, że wśród absolwentów średnich szkół prawniczych $44 \%$ z nich zostało sędziami, a pozostali prokuratorami ${ }^{15}$.

Na marginesie należy zaznaczyć, że od kwietnia 1948 roku do kwietnia 1952 roku w Toruniu istniała prawnicza szkoła średnia Ministerstwa Sprawiedliwości, w której uczono słuchaczy w zakresie prokuratorsko-sędziowskim. Kurs ukończyło stu dziewięćdziesięciu słuchaczy ${ }^{16}$.

Niewątpliwie przyczyną reform dotyczących kształcenia prawników, a polegających na skróceniu ich nauki, była chęć jak najszybszej wymiany kadry w wymiarze sprawiedliwości. Już kształt studiów, a mianowicie nacisk na przedmioty dogmatyczne, który ujawnia się w liczbie przedmiotów oraz godzin tych przedmiotów, daje podstawy, by sądzić, że ówczesnej władzy nie zależało na wykształceniu młodych ludzi na światłych prawników, lecz jedynie na wprowadzeniu do organów wymiaru sprawiedliwości osób o odpowiednim światopoglądzie, zgodnym z kierunkami wytyczonymi przez władzę.

W roku 1952/1953 Ministerstwo odstąpiło od studiów trzyletnich na rzecz czteroletnich. Dla Uniwersytetu Mikołaja Kopernika w Toruniu nie miało to jednak w tamtym okresie znaczenia, albowiem w latach w roku 1951/1952 wstrzymano nabór na Wydział Prawa. Jako podstawę zawieszenia działalności Wydziału Prawa wskazuje się względy polityczne, a przede wszystkim zwyczaje kadry profesorskiej, sprzeczne z dążeniami centralistycznymi władzy państwowej, wyso-

norzędnych oraz warunków i trybu ich nadawania w szkołach wyższych, M.P. z 1952 r. poz. 80 nr 1295 z dnia 24 września 1952 roku.

15 M. Zaborski, Szkolenie „, sędziów nowego typu” w Polsce Ludowej, „Palestra” 1998, nr 1-2, s. 88 .

16 Ibidem, s. 86. 
kie wymagania egzaminacyjne, niewielkie upartyjnienie pracowników Wydziału Prawa, ale także niska dyscyplina studiów wśród studentów, którzy chcieli jak najszybciej uzyskać dyplom uniwersytecki ${ }^{17}$. Ostatni rocznik z pierwszego okresu istnienia Wydziału kończył studia w 1953 roku $^{18}$.

Dzięki staraniom władz uczelni, a zwłaszcza Wojciecha Hejnosza i Zbigniewa Zdrójkowskiego ${ }^{19}$, w roku 1958/1959 wznowiono nabór na studia na Wydziale Prawa Uniwersytetu Mikołaja Kopernika ${ }^{20}$. Wprawdzie nabór ogłoszono późno, jednakże liczba zgłoszeń przekroczyła trzykrotnie limit miejsc wyznaczony przez Ministerstwo ${ }^{21}$.

W początkowych latach funkcjonowania odbudowanego Wydziału Prawa prowadzono zajęcia według planów z 1952/1953, przy czym usunięto przedmioty: ustrój państwowy ZSRR, materializm dialektyczny, organizację wymiaru sprawiedliwości, wstęp do nauki o państwie i prawie. Wprowadzono natomiast prawo rolne. Nadal nie prowadzono ćwiczeń z prawa rzymskiego ${ }^{22}$, prowadzono zaś zajęcia z wychowania fizycznego oraz szkolenie wojskowe. Studenci zobowiązani byli do odbywania praktyk studenckich. Od roku 1956/1957 studia prawnicze były pięcioletnie ${ }^{23}$. Po odwilży roku 1956 zrezygnowano między innymi z podstaw marksizmu-leninizmu. Zrezygnowano także z formalnej dyscypliny studiów, pozwalając radom wydziałów na większą samodzielność ${ }^{24}$.

W pierwszych trzech latach funkcjonowania reaktywowanego Wydziału Prawa powołano katedry: Teorii Państwa i Prawa, Powszechnej Historii Państwa i Prawa, Prawa Rzymskiego, Prawa Państwowego, Prawa i Postępowania Karnego, Prawa i Postępowania Cywilnego, Prawa Międzynarodowego Publicznego, Prawa Administracyjnego, Prawa Finansowego, Doktryn Polityczno-Prawnych oraz Zakład Prawa Pracy ${ }^{25}$. Wydział tak ukształtowany umożliwiał prowadzenie zajęć dydaktycznych dla studentów prawa.

17 K. Kamińska, Dzieje Wydziału Prawa i Administracji w latach 1945-2005 oraz Wydziału Nauk Ekonomicznych i Zarządzania w latach 1968-2005, [w:] 60-lecie Uniwersytetu Mikołaja Kopernika w Toruniu, red. C. Łapicz, W. Wróblewski, Toruń 2005-2006, s. 110.

18 E. Gajda, op. cit., s. 19.

19 Jak wspomina prof. Stanisław Salmonowicz, Wydział Prawa Uniwersytetu Mikołaja Kopernika w Toruniu powstał wyłącznie dzięki staraniom zakulisowym prof. Zbigniewa Zdrójkowskiego, który miał ogromny talent organizatorski, a także umiejętność zdobywania dofinansowań i wydawania publikacji (zob. S. Salmonowicz, Życie jak osioł ucieka... Wspomnienia, Bydgoszcz-Gdańsk 2014, s. 193-194, https://doi.org/10.14746/cph.2014.46.2.19).

20 E. Gajda, op. cit., s 19-20.

21 W. Dawidowicz, Uniwersytet Mikołaja Kopernika w Toruniu 1956-1965, Toruń 1965, s. 133.

22 Prawo rzymskie było jedynym przedmiotem, w którym wraz z wykładem nie prowadzono ćwiczeń.

23 K. Wojtczak, O reformach studiów prawniczych i nauczaniu prawa w Polsce w latach 1918 2015, ,Studia Prawa Publicznego” 2015, nr 1, s. 55.

24 P. Kładoczny, op. cit., s. 93.

25 E. Gajda, op. cit., s. 20. 
Już na początku działalności reaktywowanego Wydziału dyskutowano nad unowocześnieniem programu nauczania. Ministerstwo Szkół Wyższych chciało bowiem powiązać pracę dydaktyczną z praktyką. Docent dr Wacław Dawidowicz widział możliwość lepszego przygotowania studentów do przyszłej pracy w organizowaniu podczas ćwiczeń rozpraw administracyjnych, które pozwoliłyby studentowi na lepsze zapoznanie się bezpośrednio z postępowaniem administracyjnym. Dziekan prof. Wojciech Hejnosz podkreślał, że zarówno treść, jak i forma prowadzenia zajęć są ważne, dlatego sposoby prowadzenia zajęć mogą być różne, a prowadzić do tego samego celu, zatem prowadzenie rozpraw z prawa cywilnego, karnego i administracyjnego, stosowane również na innych uczelniach, wprowadzone zostanie na Wydziale Prawa UMK. Docent dr Witold Warkałło uważał za konieczne stosowanie tablic synoptycznych i wykresów ${ }^{26}$.

Program nauczania prawa na Uniwersytecie Mikołaja Kopernika w Toruniu od roku akademickiego 1960/1961 przedstawiał się następująco: na pierwszym roku studiów prowadzono zajęcia z powszechnej historii państwa i prawa (wykład trzy godziny tygodniowo, ćwiczenia dwie godziny tygodniowo), historii państwa i prawa polskiego (wykład trzy godziny tygodniowo, ćwiczenia dwie godziny tygodniowo), teoria państwa i prawa wykład dwie godziny tygodniowo w pierwszym semestrze, trzy godziny tygodniowo w drugim semestrze, ćwiczenia dwie godziny tygodniowo), ekonomii politycznej (wykład dwie godziny tygodniowo, ćwiczenia jedna godzina tygodniowo), logiki (wykład dwie godziny tygodniowo), łaciny — wprowadzono ją ponownie wzorem Uniwersytetu Poznańskiego ${ }^{27}$. Przez pierwsze trzy lata studiów każdy student musiał też uczyć się nowożytnego języka obcego spośród czterech do wyboru: niemieckiego, francuskiego, angielskiego oraz rosyjskiego, a także miał zajęcia ze studium wojskowego. Wychowanie fizyczne było obowiązkowe na pierwszym i drugim roku studiów — w wymiarze dwóch godzin tygodniowo.

$\mathrm{Na}$ drugim roku studiów prowadzono obowiązkowe wykłady z historii doktryn polityczno-prawnych (dwie godziny tygodniowo), prawa rzymskiego (wykład - dwie godziny tygodniowo, ćwiczenia dwie godziny tygodniowo), prawa państwowego (trzy godziny tygodniowo w trzecim semestrze i dwie godziny tygodniowo w czwartym semestrze, ćwiczenia dwie godziny tygodniowo), prawo karnego (wykład - trzy godziny tygodniowo, ćwiczenia dwie godziny tygodniowo) oraz ekonomii (wykład — dwie godziny tygodniowo, ćwiczenia — jedna godzina tygodniowo).

$\mathrm{Na}$ trzecim roku obowiązywały przedmioty: postępowanie karne (wykład trzy godziny tygodniowo w piątym semestrze, dwie godziny tygodniowo w szóstym semestrze, ćwiczenia — dwie godziny tygodniowo w piątym i szóstym

26 Protokół z posiedzenia Rady Wydziału Prawa UMK z 22.01.1959 roku, Archiwum Uniwersytetu Mikołaja Kopernika w Toruniu, sygn. WP-13/1.

27 Ibidem. 
semestrze), organizacja wymiaru sprawiedliwości (wykład — dwie godziny tygodniowo), prawo administracyjne (wykład — trzy godziny tygodniowo, ćwiczenia - dwie godziny tygodniowo), prawo międzynarodowe (wykład i ćwiczenia po dwie godziny tygodniowo), filozofia (wykład i ćwiczenia po dwie godziny tygodniowo), proseminarium (wybierane przez studentów, prowadzone w formie ćwiczeń dwie godziny tygodniowo).

$\mathrm{Na}$ czwartym roku wykładano: prawo cywilne (wykład — cztery godziny tygodniowo, ćwiczenia - dwie godziny tygodniowo), prawo rodzinne, prawo finansowe (wykład - dwie godziny tygodniowo, ćwiczenia - dwie godziny tygodniowo), prawo pracy (wykład - trzy godziny tygodniowo, ćwiczenia dwie godziny tygodniowo w ósmym semestrze), prawo rolne (wykład i ćwiczenia po dwie godziny tygodniowo w siódmym semestrze), główne zagadnienia filozofii (które były przedmiotem jednosemestralnym, wykład i ćwiczenia po dwie godziny tygodniowo), wykład uzupełniający oraz seminarium ${ }^{28}$. W siódmym semestrze studenci zobowiązani byli odbyć praktyki administracyjne.

Na piątym roku studenci, którzy przygotowywali się do złożenia prac magisterskich, mieli mniej zajęć. Wykłady obowiązkowe w dziewiątym semestrze prowadzone były z prawa międzynarodowego prywatnego (dwie godziny tygodniowo) oraz wykład uzupełniający (dwie godziny tygodniowo), natomiast przez cały rok studenci byli zobowiązani do uczestniczenia w seminarium magisterskim (dwie godziny tygodniowo).

Ustawa o szkolnictwie wyższym z dnia 5 listopada 1958 roku przewidywała w art. 34 ust. 2 pkt 3, że do rady wydziału należy uchwalanie szczegółowych programów nauczania ${ }^{29}$. Mając takie uprawnienie, dziekan Wydziału Prawa wystąpił do Ministerstwa Szkół Wyższych o zatwierdzenie zmian w planie studiów prawniczych na Wydziale Prawa Uniwersytetu Mikołaja Kopernika w Toruniu. Minister Szkolnictwa Wyższego zatwierdził zmiany 28 maja 1962 roku $^{30}$.

Na posiedzeniu Rady Wydziału Prawa w dniu 4 września 1962 roku szeroko dyskutowano nad zmianami programu nauczania. W związku z działalnością dydaktyczną Katedry Ekonomii Politycznej zapadła jednomyślna uchwała o upoważnieniu adiunkta dr. Ludwika Bilińskiego do prowadzenia wykładów o ekonomii politycznej dla studentów pierwszego roku studiów. Jednocześnie podjęto decyzję o przedłużeniu z nim umowy zlecenia na rok akademicki 1962/1963. Do prowadzenia wykładów ze wstępu do nauki o państwie i prawie postanowiono jedno-

28 Wykłady uzupełniające były prowadzone dla studentów ostatnich lat prawa. Wykłady te dotyczyły problematyki bardziej zaawansowanej, szczegółowej. Student podczas wykładów obowiązkowych zapoznawał się z ogólnymi zagadnieniami, natomiast wykład uzupełniający miał na celu rozszerzenie materii, z którą student zapoznał się podczas wykładów obowiązkowych. Student mógł sam wybrać wykład uzupełniający, zgodnie z jego zainteresowaniami naukowymi.

29 Ustawa o szkolnictwie wyższym z dnia 5 listopada 1958 roku, Dz.U. 1958 Nr 68, poz. 336.

30 Protokół Rady Wydziału Prawa z dnia 4 września 1962 roku, Archiwum Uniwersytetu Mikołaja Kopernika w Toruniu, sygn. WP-13/3. 
głośną uchwałą upoważnić adiunkta dr. Jerzego Nowaczyka, któremu w związku z tym przedłużono umowę zlecenia na rok akademicki 1962/1963. Prowadzenie wykładu z przedmiotu logika (z metodyką pracy umysłowej studenta) Rada Wydziału jednogłośnie zleciła dr. Franciszkowi Indanowi. Rada przyjęła do wiadomości oświadczenie kierownika Katedry Powszechnej Historii Państwa i Prawa doc. Z. Zdrójkowskiego, że wykłady i ćwiczenia będą prowadzone zgodnie z nowym planem studiów. Odnośnie do liczebności grup ćwiczeniowych postanowiono, jednogłośną uchwałą powziętą na wniosek prof. dr. Kazimierza Biskupskiego, stosować się w miarę realnych możliwości do odpowiednich w tym zakresie przepisów i instrukcji Ministerstwa Szkolnictwa Wyższego i nie tworzyć grup nazbyt wielkich, które utrudniają zajęcia dydaktyczne. Uchwałą Rady przyjęto, że z przedmiotu prawo rzymskie będą prowadzone ćwiczenia w liczbie trzydziestu godzin. Zwiększono też liczbę godzin z przedmiotu prawo państwowe. Nie przyjęto uchwały o zwiększonej liczbie godzin nauki języka rosyjskiego, bowiem tego języka studenci uczyli się już w szkole średniej. Rada Wydziału podjęła uchwałę o prowadzeniu nauki łaciny także na drugim roku studiów. Po czwartym semestrze miał być przeprowadzony egzamin z łaciny. Wykład z przedmiotu historia doktryn polityczno-prawnych zgodnie ze zmienionym planem studiów miał się odbyć dopiero w roku akademickim 1963/1964, z przerwą w roku akademickim 1962/1963. Rada Wydziału po wysłuchaniu opinii kierownika Katedry doc. dr. Wiktora Kornatowskiego oraz po zapoznaniu się z planem naukowym Katedry, przewidzianym na rok akademicki 1962/1963, a także z uwagi na planowany wyjazd zagraniczny doc. W. Kornatowskiego, po dyskusji podjęła jednogłośną uchwałę o wystąpieniu do Ministerstwa Szkół Wyższych z wnioskiem o zezwolenie na przesunięcie przerwy, na rok akademicki 1963/1964 i normalne prowadzenie zajęć w roku 1962/1963. Rada zleciła prowadzenie przedmiotu prawo obrotu uspołecznionego mgr Paulinie Bubińskiej, która przygotowywała pracę doktorską pod kierunkiem prof. dr. Stefana Buczkowskiego i doktorat miała uzyskać w lutym 1963 roku. Wniosek o zaangażowanie mgr P. Bubińskiej złożył prof. dr Stanisław Matysik. Jednogłośnie podjęto uchwałę o upoważnieniu do prowadzenia wykładów z prawa rolnego adiunkta dr. Józefa Piszczka oraz adiunkta dr. Jana Naziębły do prowadzenia obowiązkowego wykładu z prawa międzynarodowego prywatnego ${ }^{31}$.

Dyskutowano również na temat wykładów uzupełniających. Konieczność ich prowadzenia pojawiła się w związku z tym, że studenci, którzy zostali przyjęci na studia prawnicze po reaktywowaniu Wydziału Prawa Uniwersytetu Mikołaja Kopernika w Toruniu, w roku akademickim 1962/1963, rozpoczynali czwarty rok studiów. Studenci na tym roku zobowiązani byli do uczestnictwa w wykładach i ćwiczeniach obowiązkowych, zgodnie z planem studiów, seminarium magisterskim oraz wykładach uzupełniających, wybieranych zgodnie z ich zainteresowaniami naukowymi. W związku z tym uchwalono, że na czwartym roku starszy

\section{Ibidem.}


wykładowca dr Jan Krajewski poprowadzi wykład monograficzny: prawo egzekucyjne sądowe w wymiarze trzydziestu godzin. Docent dr Aleksander Kunicki będzie prowadzić w siódmym semestrze w wymiarze trzydziestu godzin wykład: posiadanie i jego ochrona, natomiast prof. S. Matysik w semestrze dziewiątym w wymiarze piętnastu godzin wykład: podstawy odpowiedzialności cywilnej za szkody wyrządzone w związku z wykorzystaniem nowych źródeł energii. Adiunktowi dr. J. Nazięble zlecono wykład postępowanie arbitrażowe — w wymiarze trzydziestu godzin. Docent dr Jerzy Śliwowski zgłosił wniosek prowadzenia przez siebie wykładu reforma prawa karnego, w wymiarze sześćdziesiąt godzin w semestrze siódmym i ósmym, natomiast dla piątego roku, w semestrze dziewiątym, wykład polskie prawo penitencjarne, w wymiarze trzydziestu godzin.

Wnioski te Rada Wydziału jednogłośnie przyjęła. Podjęła też uchwałę o prowadzenie przez prof. dr Janinę Hurynowicz wykładów z psychologii sądowej. Zadecydowano o przeprowadzeniu rozmów z prof. dr. Stanisławem Manczarskim w sprawie prowadzenia przez niego wykładów uzupełniających z medycyny sądowej $^{32}$. Ostatecznie Rada zleciła przeprowadzenie wykładu z kryminalistyki adiunktowi Uniwersytetu im. Adama Mickiewicza dr. Andrzejowi Szwarcowi ${ }^{33}$, a także dr. Wiesławowi Daszkiewiczowi prowadzenie na piątym roku w wymiarze trzydziestu godzin wykładu uzupełniającego wojskowy proces karny.

Zgodnie $\mathrm{z}$ wnioskiem prof. K. Biskupskiego postanowiono w siódmym semestrze zorganizować wykład wybrane zagadnienia z socjologii, uwzględniający metody nauczania zjawisk społecznych. Profesor Biskupski zaproponował prowadzenie wykładu przez prof. dr. Tadeusza Szczurkiewicza, w wymiarze trzydziestu godzin, a zakończenie zajęć egzaminem. Według założenia wykład skierowany był dla studentów zainteresowanych problematyką prawa państwowego, administracyjnego i karnego. Upoważniono dr. Edmunda Mizerskiego do prowadzenia wykładu ustrój Związku Radzieckiego na tle uwag o ustroju innych państw socjalistycznych, w ósmym semestrze w wymiarze trzydziestu godzin. Również na wniosek prof. K. Biskupskiego powierzono dr. Mieczysławowi Szererowi prowadzenie na warunkach zlecenia wykładu: ustrój państw anglosaskich w dziewiątym semestrze w wymiarze trzydziestu godzin. Wykłady te kończyć się miały egzaminami.

Docent dr Zbigniew Jaśkiewicz zgłosił wniosek prowadzenia przez siebie wykładu bankowość w państwach kapitalistycznych, w wymiarze trzydziestu godzin w dziewiątym semestrze, który Rada Wydziału jednogłośnie uchwaliła. Jednocześnie jako kurator Katedry Statystyki doc. Jaśkiewicz zgłosił wniosek o powierzenie prof. dr. Maksymilianowi Ziomkowi z Wyższej Szkoły Ekonomicznej w Sopocie wykładów ze statystyki - dla seminariów prawa finansowego, administracyjnego i karnego - w wymiarze trzydziestu godzin w ósmym semestrze i w wymiarze trzydziestu godzin w semestrze dziewiątym, co Rada przyjęła. Rada,

32 Ibidem.

33 Protokół z posiedzenia Rady Wydziału z dnia 26 września 1962 roku Archiwum Uniwersytetu Mikołaja Kopernika w Toruniu, sygn. WP-13/3. 
na wniosek doc. Jaśkiewicza, powierzyła doc. dr. Władysławowi Nowaczykowi z Wyższej Szkoły Ekonomicznej w Sopocie prowadzenie zajęć z rachunkowości, przeznaczonych dla seminariów z prawa administracyjnego, karnego i finansowego, a prowadzonych w wymiarze trzydziestu godzin w ósmym semestrze oraz trzydziestu godzin w dziewiątym semestrze.

Docent dr Stanisław Nahlik zaproponował upoważnienie mgr. Janusza Symonidesa do prowadzenia w ósmym semestrze w wymiarze piętnastu godzin wykładu: rozbrojenie jako problem prawa i stosunków międzynarodowych albo zagadnienia kontroli wykonywania zobowiązań międzynarodowych. W przedmiocie tej propozycji Rada Wydziału podjęła jednogłośną uchwałę pozytywną, jednakże na kolejnym posiedzeniu, które odbyło się 26 września 1962 roku, wycofał się ze swojej propozycji, argumentując to faktem, że mgr Symonides nadal pracuje nad wykończeniem swojej pracy doktorskiej i nie będzie mógł przeprowadzić wykładu uzupełniającego ${ }^{34}$. Jednocześnie doc. S. Nahlik, zgłosił propozycję prowadzenia przez siebie wykładów w wymiarze piętnastu godzin: prawo dyplomatyczne (konwencja wiedeńska w 1961 roku oraz klauzule dyplomatyczne prawa polskiego) albo ochrona dóbr kulturalnych w prawie międzynarodowym. Rada podjęła uchwałę o powierzeniu doc. S. Nahlikowi wykładu, pod warunkiem że będzie on nadal zatrudniony na Uniwersytecie Mikołaja Kopernika w Toruniu ${ }^{35}$.

Zgodnie z postanowieniami zapadłymi na Radzie Wydziału 4 września 1962 roku kierownicy katedr na następnym posiedzeniu Rady Wydziału — 26 września 1962 roku, zobowiązani zostali do przedstawienia wykładów uzupełniających w roku 1962/1963 36 .

Ostatecznie kierownicy katedr, na posiedzeniu Rady Wydziału w dniu 26 września 1962 roku przedstawili szeroką propozycję prowadzenia wykładów uzupełniających w roku akademicki 1962/1963.

Kierownik Katedry Postępowania Cywilnego prof. Matysik zaproponował wykład dr. Naziębły postępowanie arbitrażowe, w wymiarze dwudziestu sześciu godzin w semestrze siódmym, wykład dr. J. Krajewskiego prawo egzekucyjne sądowe, w wymiarze dwudziestu sześciu godzin w semestrze ósmym, oraz wykład doc. A. Kunickiego posiadanie i jego ochrona, w wymiarze dwudziestu sześciu godzin w semestrze dziewiątym, lub wykład prof. S. Matysika prawo morskie. Wykłady prawo morskie oraz posiadanie i jego ochrona zostały zaproponowane też przez kierownika Katedry Prawa Cywilnego.

Kierownik Katedry Teorii Państwa i Prawa doc. Kornatowski ${ }^{37}$ zaproponował swój wykład: poprzednicy współczesnego socjalizmu (zagadnienia wybrane),

34 Ibidem.

35 Protokół z posiedzenia Rady Wydziału z dnia 4 września 1962 roku.

36 Ibidem.

37 Wiktor Kornatowski został kierownikiem Katedry w 1961 roku — po prof. Kazimierzu Biskupskim. Specjalizował się w historii doktryn polityczno-prawnych, a w omawianym okresie nie istniała jeszcze wyodrębniona Katedra Doktryn Polityczno-Prawnych.

Prawo 328, 2019

(C) for this edition by CNS 
w wymiarze piętnastu godzin, i wykład dr. Edmunda Mizerskiego: ustrój Związku Radzieckiego na tle wybranych zagadnień ustrojowych krajów demokracji ludowej, w wymiarze trzydziestu godzin w ósmym semestrze. Wykład dr. Mizerskiego został zaproponowany także przez kierowników katedr Prawa Państwowego i Prawa Administracyjnego.

Kierownik Katedry Prawa Cywilnego prof. Matysik zaproponował prowadzony przez siebie wykład: podstawy odpowiedzialności za szkody wyrządzone w związku z wykorzystaniem nowych źródeł energii, w wymiarze dwudziestu sześciu godzin w semestrze siódmym. Wykład ten zaproponował też kierownik Katedry Prawa Międzynarodowego Publicznego.

Katedra Prawa Międzynarodowego Publicznego pod kierownictwem doc. S. Nahlika zgłosiła gotowość prowadzenia wykładu prof. dr. Remigiusza Zaorskiego międzynarodowe prawo morskie, w wymiarze trzydziestu godzin w semestrze dziewiątym, wykładu doc. Nahlika prawo dyplomatyczne, w wymiarze piętnastu godzin w semestrze dziewiątym, wykładu prof. T. Szczurkiewicza socjologia, w wymiarze trzydziestu godzin w semestrze siódmym. Wykład prof. Szczurkiewicza proponowały też katedry Prawa Państwowego oraz Historii Państwa i Prawa Polskiego.

Katedra Prawa Państwowego, kierowana przez prof. K. Biskupskiego, zaproponowała wykład doc. dr. Ludwika Bara ustroje anglosaskie z uwzględnieniem zarządu lokalnego - w wymiarze trzydziestu godzin w semestrze dziewiątym.

Kierownik Katedry Powszechnej Historii Państwa i Prawa oraz Katedry Historii Państwa i Prawa Polskiego prof. W. Hejnosz wyraził gotowość prowadzenia wykładu wstęp do nauk pomocniczych historii, w wymiarze trzydziestu godzin w semestrze dziewiątym ${ }^{38}$. Propozycję tę poparli kierownicy katedr Teorii Państwa i Prawa.

Katedra Prawa Administracyjnego, kierowana przez prof. W. Dawidowicza, wyraziła gotowość do prowadzenia wykładu prof. M. Ziomka statystyka, w wymiarze trzydziestu godzin w semestrze siódmym. Propozycję tę przedstawił również kierownik Katedry Prawa Finansowego.

Kierownik Katedry Prawa Karnego doc. J. Śliwowski zaproponował prowadzenie przez siebie wykładu analiza projektu kodeksu karnego, w wymiarze sześćdziesięciu godzin w semestrze siódmym i ósmym, oraz polskie prawo penitencjarne — w wymiarze sześćdziesięciu godzin w semestrze siódmym i ósmym, natomiast kierownik Katedry Postępowania Karnego doc. W. Daszkiewicz wykład wojskowy

38 Katedra Historii Państwa i Prawa Polskiego jako jedyna ocalała po zawieszeniu działalności Wydziału w roku 1951. Została ona wówczas przeniesiona na Wydział Humanistyczny. Po reaktywacji Wydziału Prawa w roku 1957 rozpoczęła działalność na Wydziale Prawa. Od początku istnienia Katedry jej pracami kierował prof. Wojciech Hejnosz, który po reaktywacji Wydziału Prawa też prowadził zajęcia na Wydziale Humanistycznym. Więcej o jego działalności działalności zob. Z. Naworski, Ze Lwowa do Torunia - rzecz o Profesorze Wojciechu Hejnoszu, [w:] Stefan Ehrenkreutz i historycy prawa okresu dwudziestolecia międzywojennego. W 70 rocznicę śmierci ostatniego Rektora Uniwersytetu Stefana Batorego w Wilnie, red. P. Dąbrowski, D. Szpoper, Gdańsk-Olsztyn 2016, k. 143-152. 
proces karny, w wymiarze trzydziestu godzin w semestrze dziewiątym, oraz wykład dr. A. Szwarca kryminalistyka, w wymiarze trzydziestu godzin w semestrze siódmym.

Katedra Prawa Finansowego pod kierownictwem doc. Jaśkiewicza podjęła się prowadzenia wykładu doc. W. Nowaczyka rachunkowość, w wymiarze trzydziestu godzin w semestrze dziewiątym, oraz wykładu prowadzonego przez kierownika Katedry: bankowość w krajach kapitalistycznych, w wymiarze trzydziestu godzin w semestrze ósmym ${ }^{39}$.

Wykłady uzupełniające wprowadzono do programu nauczania na Wydziale Prawa Uniwersytetu Mikołaja Kopernika w Toruniu dopiero w roku akademickim 1962/1963, albowiem wcześniej nie było to konieczne ani prawdopodobnie nie było to możliwe ze względu na trudności kadrowe, związane z reaktywacją i nową organizacją procesu dydaktycznego na Wydziale. Wskazać przy tym należy, że wykłady uzupełniające były prowadzone dopiero na czwartym i piątym roku studiów i obowiązywały studentów wyższych lat. Dopiero w latach 1962/1963 studenci, którzy rozpoczynali naukę na Wydziale w pierwszych latach jego funkcjonowania, mogli i musieli, zgodnie z programem studiów, uczestniczyć w wykładach dodatkowych. Niemniej jednak należy zauważyć, że oferta dydaktyczna była nader bogata. Jedynie na marginesie należy wskazać, że niektóre wykłady uzupełniające zaproponowane studentom, były mocno osadzone w ówczesnym ustroju politycznym.

W omawianym okresie działalności Wydziału Prawa Uniwersytetu Mikołaja Kopernika w Toruniu największym problemem było zapewnienie kadry dydaktycznej, która umożliwiłaby prowadzenie kształcenia. Na początku działalności Wydziału, w roku 1945, wprawdzie zorganizowano szesnaście katedr, jednak nie wszystkie udało się obsadzić. Początkowo obsadzono Katedrę Historii Ustroju i Państwa Polskiego, której kierownikiem został prof. Hejnosz, Katedrę Historii Prawa na Zachodzie Europy, kierowaną przez prof. Karola Koranyiego ${ }^{40}$, zawiadującego także Katedrą Nauki o Państwie i Prawie Państwowym. Obsadzono też Katedrę Prawa Kościelnego - prof. Michał Wyszyński ${ }^{41}$, Katedrę Nauki Skarbowości i Prawa Skarbowego - prof. Leon Kurowski, Katedrę Prawa Narodów prof. Władysław Namysłowski, Katedrę Socjologii, którą kierował prof. Szczurkiewicz, oraz Katedrę Teorii Prawa, pierwotnie pod kierownictwem zastępcy prof. dr Eugeniusza Bautry, a następnie prof. Michała Wyszyńskiego ${ }^{42}$. Katedrą Prawa Rzymskiego kierował początkowo dr Witold Lis Olszewski, a od roku akademickiego 1948/1949 prof. Wyszyński, Katedrą Ekonomii Politycznej — mgr Adolf

39 Protokół posiedzenia Rady Wydziału Prawa z dnia 26 września 1962 roku.

40 W roku 1950 Katedra Historii Prawa na Zachodzie Europy została przemianowana na Katedrę Powszechnej Historii Państwa i Prawa.

41 Katedra została zlikwidowana w roku akademickim 1948/1949.

42 K. Kamińska, M. Parszutowicz, Z. Witkowski, 60 lat Wydziału Prawa i Administracji 1945-2005 Uniwersytetu Mikołaja Kopernika w Toruniu, Toruń 2005-2006, s. 21. 
Tokarski, a następnie zastępca prof. Władysław Hegemajer, Katedrą Nauki Administracji i Prawa Administracyjnego pierwotnie kierował mgr W. Reiss, a od roku akademickiego 1948/1949 doc. Wacław Brzeziński. Katedra Statystyki kierowana była przez dr. Stefana Prószyńskiego, a Katedra Prawa Handlowego i Wekslowego przez dr. S. Buczkowskiego. Katedrą Prawa Cywilnego pierwotnie kierował dr Stefan Dębiński, a następnie od roku akademickiego 1948/1949 dr A. Kunicki. Katedra Prawa Karnego została obsadzona w roku 1948/1949 przez dr. J. Śliwowskiego. Katedrę Postępowania Cywilnego objął dr W. Lis Olszewski. W roku akademickim 1948/1949 i na Wydziale Prawa pracowało tylko sześciu profesorów, pięciu adiunktów, siedmiu starszych asystentów, czternastu młodszych asystentów oraz pięciu zastępców asystentów ${ }^{43}$. Niewątpliwie kadra dydaktyczna była bardzo skromna, zważywszy, że w roku akademickim 1945/1946 na Wydziale studiowało 813 studentów. Tak duży nabór spowodowany był tym, że przyjmowano studentów na wszystkie lata studiów, aby umożliwić ukończenie studiów tym, którym naukę przerwała okupacja. W następnych latach na Wydziale Prawa Uniwersytetu Mikołaja Kopernika studiowało: w roku 1946/1947 — 671 studentów, w roku 1947/1948 — 1022 studentów, w roku 1948/1949 — 1507 studentów, w roku 1949/1950 — 1356 studentów, w roku 1950/1951 - 1265 studentów, w roku 1951/1952 — 854 studentów, w roku 1952/1953 - 252 studentów $^{44}$.

Po reaktywacji Wydziału Prawa w roku akademickim 1958/1959 przyjęto dziewięćdziesięciu studentów ${ }^{45}$, jednakże zainteresowanych było trzykrotnie więcej, mimo że nabór ogłoszono późno ${ }^{46}$. W kolejnych latach na Wydziale studiowało: w roku 1959/1960 — 254 studentów, w roku 1960/1961 — 381 studentów, w roku 1961/1962 — 473 studentów, w roku 1962/1963 - 623 studentów ${ }^{47}$. W tym okresie na Wydziale Prawa toruńskiego Uniwersytetu pracowało trzech profesorów zwyczajnych (K. Biskupski, W. Hejnosz, S. Matysik), sześciu profesorów nadzwyczajnych, dziewięciu docentów, trzech starszych wykładowców, dwudziestu jeden adiunktów oraz dwudziestu trzech asystentów ${ }^{48}$.

Zaprezentowane opracowanie przedstawia jedynie programy nauczania prawa na Wydziale Prawa Uniwersytetu Mikołaja Kopernika w Toruniu w początkowym okresie jego funkcjonowania. Programy te różnią się od współczesnych programów nauczania prawa. Obecnie dąży się bowiem do ujednolicenia programów w całej Polsce, a nawet Europie. Konieczność ujednolicania kształcenia studentów zapoczątkowana została wraz z podpisaniem przez Polskę w dniu 19 czerwca 1999 roku deklaracji bolońskiej, której celem było zbliżenie systemów kształcenia wyższego w krajach europejskich.
43 Ibidem, s. 22.
44 Ibidem, s. 23.
45 Ibidem, s. 29.
46 W. Dawidowicz, Uniwersytet Mikołaja Kopernika w Toruniu 1956-1965, Toruń 1965, s. 133.
47 K. Kamińska, M. Parszutowicz, Z. Witkowski, op. cit., s. 30.
48 W. Dawidowicz, op. cit., s. 142-147. 
W omawianym okresie cykl kształcenia studentów na wydziałach prawa wydłużył się z czteroletniego na pięcioletni, przyjął zatem kształt współczesny, odrzucając proponowany w latach 1946/1947 model kształcenia opartego na cyklu dwustopniowym. Zauważyć przy tym należy, że w Polsce, po wprowadzeniu systemu bolońskiego, jednostopniowymi studiami magisterskimi pozostały nieliczne kierunki, między innymi prawo, medycyna i psychologia. Studia prawnicze pozostały pięcioletnie.

Pracownicy naukowi Wydziału Prawa Uniwersytetu Mikołaja Kopernika w Toruniu dążyli do unowocześnienia procesu dydaktycznego przez wprowadzanie nowych metod i programów nauczania prawa. Profesorowie sugerowali przeprowadzanie ćwiczeń ze studentami w taki sposób, żeby przygotować ich do wykonywania zawodów prawniczych. Świadczy to o dążeniu Wydziału Prawa UMK do praktycznego przygotowania studentów do przyszłej pracy. Należy podkreślić, że również Ministerstwu Szkół Wyższych zależało na praktycznym przygotowaniu studentów do pracy. Nie należy zapominać, że proces boloński też służy dostosowywaniu systemów kształcenia do potrzeb rynku pracy. Dziś nadal toczy się dyskusja nad kształtem studiów prawniczych. Słuszne jest jednak pozostawienie studiów prawniczych studiami jednolitymi, podczas których student zdobędzie konieczną wiedzę w zakresie nauk historycznoprawnych, teoretycznych, dyscyplin dogmatycznych oraz umiejętności w zakresie rozumowania, logiki i argumentacji prawniczej. Konieczne jest bowiem, aby absolwent studiów prawniczych posiadł teoretyczną wiedzę oraz umiejętności akademickie. Praktyczne przygotowanie do wykonywania zawodów prawniczych powinno odbywać się, jak dotychczas, podczas aplikacji.

Problemem aktualnym zarówno w początkowym okresie funkcjonowania Wydziału Prawa Uniwersytetu Mikołaja Kopernika w Toruniu, jak i dziś jest autonomia wydziałów w zakresie kształtowania planu i programu nauczania prawa. Ujednolicenie procesu kształcenia podczas przeprowadzania procesu bolońskiego miało doprowadzić do zwiększenia standardów kształcenia, jednak dostosowanie się do regulacji ogranicza autonomię szkół wyższych w zakresie kształtowania procesu dydaktycznego oraz samodzielnego decydowania o programie nauczania prawa realizowanym na wydziale. Ostrożnie zatem należy podchodzić do ujednolicania procesu kształcenia, w tym praktycznego przygotowywania studenta do wyjścia na rynek pracy, działania takie mogą bowiem spowodować, że kształcenie w zakresie prawa będzie przypominało kształcenie zawodowe, a student podczas studiów nie zdobędzie odpowiedniej wiedzy teoretycznej, która pozwoli na samodzielne posługiwanie się regulacjami prawnymi, bez względu na ich treść.

Proces boloński nie wyklucza nadania uczelniom większej autonomii, jednakże nie można mówić o większej autonomii uczelni wyższych bez odpowiednich środków finansowych przeznaczonych na badania naukowe oraz na podniesienie statusu pracownikom uczelni. Należy zauważyć, że autonomia uczelni wyższych w zakresie modelowania programów nauczania w omawianym okresie i obecnie 
jest niewielka. Podstawowy program nauczania prawa w latach 1945-1962 narzucany był rozporządzeniami. O pewnej autonomii można jedynie mówić co do zajęć dodatkowych i fakultatywnych, których liczba nie była dowolna ze względu na ograniczony budżet oraz możliwości kadrowe. Obecnie natomiast autonomia w zakresie kształtowania programów nauczania prawa jest ograniczona z powodu dążności do ujednolicenia procesu kształcenia w całej Europie, co może negatywnie przekładać się na rozwój nauki oraz niszczenie potencjału naukowego studentów, szczególnie na wydziałach o wysokim standardzie. Jednak ograniczonej autonomii wydziałów prawa w zakresie programów nauczania nie można oceniać wyłącznie negatywnie. Niestworzenie jakichkolwiek ram programowych mogłoby prowadzić do dowolnego kształtowania programów nauczania prawa, co mogłoby negatywnie wpłynąć na jakość kształcenia studentów.

\section{Bibliografia}

Dawidowicz W., Uniwersytet Mikołaja Kopernika w Toruniu 1956-1965, Toruń 1965.

Gajda E., Krótki rys historii Wydziału Prawa i Administracji UMK w Toruniu, [w:] Ze Złotej Księgi Wydziału Prawa i Administracji Uniwersytetu Mikołaja Kopernika, red. S. Salmonowicz, M. Sobczyk, Toruń 2015.

Kamińska K., Dzieje Wydziału Prawa i Administracji w latach 1945-2005 oraz Wydziału Nauk Ekonomicznych i Zarzadzania w latach 1968-2005, [w:] 60-lecie Uniwersytetu Mikołaja Kopernika w Toruniu, red. C. Łapicz, W. Wróblewski, Toruń 2005-2006.

Kamińska K., Parszutowicz M., Witkowski Z., 60 lat Wydziału Prawa i Administracji 1945-2005 Uniwersytetu Mikołaja Kopernika w Toruniu, Torun 2005-2006.

Kładoczny P., Kształcenie prawników w Polsce w latach 1944-1989, „Studia Iuridica” 35, 1998, s. $89-113$.

Marszał M., Spór o model prawnika w Drugiej Rzeczypospolitej, „Krakowskie Studia z Historii Państwa i Prawa" 8, 2015, z. 2, s. 173-183.

Naworski Z., Ze Lwowa do Torunia - rzecz o Profesorze Wojciechu Hejnoszu, [w:] Stefan Ehrenkreutz $i$ historycy prawa okresu dwudziestolecia międzywojennego. W 70 rocznicę śmierci ostatniego Rektora Uniwersytetu Stefana Batorego w Wilnie, red. P. Dąbrowski, D. Szpoper, Gdańsk-Olsztyn 2016.

Salmonowicz S., Życie jak osioł ucieka... Wspomnienia, Bydgoszcz-Gdańsk 2014.

Watoła A., Reforma studiów prawnych w latach 1949-1950, „Miscellanea Historico-Iuridica” 14, 2015, z. 2.

Wojtczak K., O reformach studiów prawniczych i nauczaniu prawa $w$ Polsce $w$ latach 1918-2015, „Studia Prawa Publicznego” 2015, nr 1, s. 31-74.

Wołodkiewicz W., Czy prawo rzymskie przestało istnieć?, „Palestra” 1997, nr 11-12.

Zaborski M., Szkolenie ,,sędziów nowego typu” w Polsce Ludowej, „Palestra” 1998, nr 1-2. 


\section{The law curriculum at the Faculty of Law, Nicolaus Copernicus University in Toruń in 1945-1962}

Summary

The aim of the article is to present the core law curriculum at the Faculty of Law, Nicolaus Copernicus University in Torun in 1945-1962, that is at the beginning of the functioning of the Faculty. The author discusses the origins and changes in the teaching of law in the analysed period.

Keywords: law curriculum, teaching of law, Faculty of Law, Nicolaus Copernicus University

\section{Ausbildungsprogramme für Recht an der Juristischen Fakultät der Nikolaus-Kopernikus-Universität Toruń in den Jahren 1945-1962}

Zusammenfassung

Der Artikel wurde der Frage der Grundausbildungsprogramme für Recht an der Juristischen Fakultät der Nikolaus-Kopernikus-Universität Toruń in den Jahren 1945-1962, also in der Anfangsphase der Arbeit der Fakultät gewidmet. Die Verfasserin schildert darin die Genese und die Änderungen des Rechtsunterrichts in der besprochenen Zeit.

Schlüsselworte: Grundausbildungsprogramm für Recht; Rechtsunterricht; Juristische Fakultät der Nikolaus-Kopernikus-Universität 